The article analyzes the activities of North Caucasian deputies in terms of solving the most pressing issues of social and economic life in the region. The scientific novelty of the research consists in considering the State Duma as the most important factor in the development of the political culture of the peoples of Russia.

The author concludes that the Duma presented new political opportunities to representatives of regions and peoples of the Empire. First of all, they could now get elected legally and legitimately for ethnic and regional representation in Russia's first Parliament; secondly, they got to represent their national interests from the Duma rostrum; and thirdly, it allowed them to establish ethnic and regional political organizations.

Keywords: State Duma of Russian Empire, North Caucasus deputies, Terek region, national elites

ДЗЮБАН Валерий Валерьевич - доктор исторических наук, кандидат педагогических наук; профессор департамента социологии, истории и философии Финансового университета при Правительстве РФ (125993, Россия, г. Москва, Ленинградский пр-кт, 49; bryanskstudzuban@mail.ru)

\title{
ДЕЯТЕЛЬНОСТЬ СОВЕТСКОЙ ВНЕШНЕЙ ВОЕННОЙ РАЗВЕДКИ В ГОДЫ ВЕЛИКОЙ ОТЕЧЕСТВЕННОЙ ВОЙНЫ 1941-1945 гr.
}

\begin{abstract}
Аннотация. Статья посвящена деятельности советской внешней военной разведки в годы Великой Отечественной войны. Автор рассматривает подвиги разведчиков в борьбе с нацистской Германией и подконтрольными ей странами, анализирует структуру разведывательных органов, работавших в тылу врага, определяет поставленные перед разведкой задачи и итоги их выполнения, оценивает вклад в победу в войне и значение разведывательных операций в общей картине событий.

Данная тема является актуальной в наши дни, когда раскрываются секретные архивы, и их содержание становится достоянием общественности, люди узнают все больше имен героев Великой Отечественной войны. Очень важно сохранить память об их подвигах в памяти российской молодежи, таким образом воспитывая в них уважение к истории нашей страны.
\end{abstract}

Ключевые слова: внешняя разведка, разведчик, тыл, контрразведка, агент, подвиг

C каждым днем от нас все сильнее отдаляется время войны, с каждым годом становится все меньше очевидцев тех событий, которые могли бы поведать о том, что было в действительности. До сих пор остаются неизвестными некоторые операции спецслужб и вклад, который они внесли в достижение Великой Победы, не оценены должным образом подвиги разведчиков, работавших в тылу врага, настоящее значение переданных ими данных, оказавших исключительно важное влияние на итоги Великой Отечественной войны.

«В настоящее время под разведкой понимается практика и теория сбора информации о противнике или конкуренте для безопасности и получения преимуществ в области вооруженных сил, политики или экономики. Это, как правило, хорошо организованные действия на правительственном или корпоративном уровне» [Рашевский 2010: 4].

В первые годы войны вопросами государственной безопасности Советского Союза занимался Народный комиссариат госбезопасности и органы военной контрразведки. Деятельность разведывательных организаций начала активизироваться в 1940 г., когда стало очевидным, что Германия готовится к нападению на Советский Союз. Подтверждением тому служили сообщения из Токио и Берна, а немного позже - и из Берлина, Вашингтона, Лондона, Анкары, 
Варшавы. Советская военная разведка, возглавляемая Ф.И. Голиковым, с лета 1940 г. следила за основными действиями немецких войск.

За 10-11 дней до начала войны было получено около 28 донесений с точной датой начала военных действий Германии против СССР. Несмотря на проведенную работу, нападение немецких войск застало советскую разведку неподготовленной, поэтому ей потребовалась реорганизация для увеличения эффективности, на что повлиял и характер войны, который на момент ее начала носил отступательный характер. Были усилены разведывательные отделы органов госбезопасности, главным разведывательным подразделением стал Народный комиссариат государственной безопасности СССР. В августе 1941 г. структура внешней разведки была выстроена в следующем порядке.

« Р Руководство разведки

- Секретариат

- Отделы:

- Центрально-европейский (Германия, Чехословакия, Венгрия, Польша, Украина)

- Балканский (Болгария, Югославия, Румыния, Греция)

- Западно-европейский (Франция, Бельгия, Италия, Португалия, Швейцария)

- Скандинавский (Норвегия, Финляндия, Дания, Швеция, Голландия)

- Англо-Американский (Англия, США, Канада, Южная Америка и отделение научно-технической разведки)

- 1-й дальневосточный (Япония, Корея, Маньчжурия)

- 2-й дальневосточный (Китай, Таиланд, Синьцзян)

- Средневосточный (Иран, Турция и арабские страны, Индия и Афганистан)

- Совколония» 1 .

В данной структуре отображено, что разведывательные действия проводились не только во вражеских странах, но и в нейтральных. Таким образом руководство СССР пыталось предотвратить обращение этих стран к фашистскому блоку и направить их интересы в сторону Советского Союза с целью найти себе союзников по обороне в лице граничащих государств и опорные пункты в странах, близких к Германии, для срыва прогерманской пропаганды и укрепления в них советской агентуры.

Нельзя оставить без внимания и деятельность научно-технической разведки, занимающейся получением сведений о научных достижениях в области военной промышленности. Так, за время войны были получены сведения о разработке атомной бомбы из различных стран и информация о достижениях Англии и США в области электроники, ракетостроения и радиотехники.

С момента вторжения Германии главной целью внешней политики правительства СССР стала организация быстрого отпора противнику и попытка создания благоприятных условий для будущей борьбы с оккупацией, а также укрепление антигитлеровской коалиции для открытия и поддержания Второго фронта в Европе [Максимов 2016: 8].

Огромное значение в разведывательной деятельности играло создание партизанских отрядов и отрядов быстрого реагирования в тылу врага, зачастую полностью отрезанных от основных сил, которые могли заниматься диверсиями в военных формированиях, на коммуникациях и промышленных объектах противника, добывать сведения о передвижениях и будущих атаках, а также срывать важные стратегические операции.

\footnotetext{
${ }^{1}$ Структура внешней разведки в военный период. - Служба внешней разведки Российской Федерации. Доступ: http://svr.gov.ru/history/stages/stage05.htm\#2 (проверено 26.02.2020).
} 
Нельзя не упомянуть имена разведчиков, чьи действия внесли неоценимый вклад в Великую Победу:

- Рихард Зорге и его сообщения о сохранении Японией нейтралитета, что позволило перебросить под Москву танковые дивизии. Именно из Японии пришло одно из первых сообщений о готовящемся нападении Германии на СССР;

- Николай Кузнецов, благодаря чьей разведывательной деятельности на Западной Украине были уничтожены 11 высокопоставленных лиц в оккупационной армии;

- Ян Черняк и развернутая им разведывательная сеть «Крона». Среди достижений этого подразделения - копия плана «Барбаросса», план наступления немцев под Курском, информация об атомных разработках Англии и о новом оружии Германии. Ни одного из членов этой организации не смогла раскрыть немецкая разведка, и на данный момент известно всего двое из 35 участников этой организации, хотя и этот факт вызывает споры;

- Анатолий Гуревич, заместитель главы «Красной капеллы» Леопольда Треппера, а позже - и глава этого движения в Брюсселе, занимавшийся поддержкой связи между антинацистскими группами разных стран, что заставляло его много ездить по странам, тем самым ставя себя под удар, т.к. он обладал большим объемом секретной информации;

- Владимир Молодцов, руководивший подпольной группой Одессы. Они занимались внезапными диверсиями: подрывом поездов и складов с припасами, минированием дорог, устранением руководящих лиц и раскрытием местоположения противника с последующими атаками. Его подразделение успешно проводило спецоперации против румынских и немецких войсковых объединений;

- Лев Маневич, который был разведчиком, специализировавшимся на авиации. Он знал несколько иностранных языков, от него поступали сведения о новейших разработках стран в области авиации, судостроения, а также грузовых перевозках врага через морские порты нескольких государств;

- Рудольф Абель, один из известнейших советских разведчиков, чье настоящее имя стало известно только после развала СССР. Он работал по всей Европе в военное время, занимался расстановкой радиоточек в разных странах. После войны его перенаправили на североамериканское направление, тогда сильно скомпрометированное, но это не помешало ему выстроить там блестящую карьеру в начале «холодной войны» [Даллес 1992: 49];

- Александр Коротков, работавший в качестве агента в нескольких европейских странах, а позднее - и в советском посольстве в Берлине перед началом Великой Отечественной войны. Он проводил операции на прифронтовых участках и сам часто представлялся немецким военнопленным, чтобы выведать нужную информацию у высокопоставленных лиц противника. Он оказался одним из немногих иностранных агентов внешней разведки СССР, кто не был репрессирован в послевоенные годы.

В период военных действий советские разведывательные и контрразведывательные подразделения провели множество оперативных мероприятий по передаче дезинформации противнику. Эти операции назывались радиоиграми [Жмакин 2017: 215].

Масштабная дезинформационная радиоигра «Монастырь» - «Березино», начавшаяся еще до нападения Германии на СССР и завершившаяся только к концу войны, была задумана как акция по введению в заблуждение немецкой стороны по поводу реального положения дел: немецкой разведке передавались данные о несуществующей религиозно-монархической организации 
«Престол» с антисоветскими настроениями. За все годы этой операции вражеской стороне было доставлена дезинформация, подготовленная в Генеральном штабе Красной армии, которая способствовала раскрытию агентуры разведки противника [Долгополов 2018: 97].

Главной целью операции «Арийцы» была дезинформация, ведущая к срыву планов диверсии и воздушного шпионажа на территории Калмыкии и Казахстана. Была предотвращена попытка создания повстанческого объединения в тылу, уничтожены 2 мощных бомбардировщика и захвачены двигатели в рабочем состоянии, убиты 33 вражеских диверсанта ${ }^{1}$.

Радиоигра «Туман» преследовала цель выявить и уничтожить новоприбывших под Москву агентов немецкой разведки, направленных по этому направлению для получения информации из Кремля и проведению террористических актов по устранению Сталина и, по возможности, других руководителей.

«Находка» как радиоигра началась почти случайно, т.к. не хватало достоверных данных и были сомнения в преданности людей Родине. Но нашей разведке удалось перевербовать агента, что помогло успешно передавать дезинформацию о движении эшелонов с войсковыми отрядами и провизией в Московской области.

Радиоигра «Янус» была призвана ввести в заблуждение немецкую разведку по поводу того, что их агентурная сеть по-настоящему работает и проводит антисоветскую пропаганду, в т.ч. против Сталина, согласно идеологии Власова, осуществляет террористические акты против руководства НКВД.

План «Ультра» по дешифровке секретных донесений, разработанный английским правительством, противопоставляемый плану «Энигма» немецкой стороны по шифровке данных, также по своей важности стоял на одном из самых высоких мест по значению вклада в поражение фашистского режима. Сталин отказывался внимать собственным органам разведки и тем более отказался слушать англичан с их разведанными, данными о дате начала вторжения Германии.

Василевский А.М. в своих мемуарах по этому поводу писал: «В чем причины столь крупного просчета этого опытного и дальновидного государственного деятеля? Прежде всего в том, что наши разведорганы, как справедливо отмечает в своих воспоминаниях Г.К. Жуков, не смогли в полной мере объективно оценивать поступавшую информацию о военных приготовлениях фашистской Германии и честно, по-партийному, докладывать ее И.В. Сталину, в этом, видимо, сыграла свою роль и некоторая обособленность Разведуправления от аппарата Генштаба» [Василевский, Конев, Рокоссовский 2016: 54].

В 1944 г. Англия в целях самозащиты перестала предоставлять расшифрованную информацию Советскому Союзу, но за все время их сотрудничества СССР получил сведения о планах вермахта на Северокавказском фронте, план Курской битвы (операция «Цитадель»). До конца войны в СССР так и не был расшифрован код «Энигмы», хотя в дешифровке обычных криптографических армейских посланий и были достигнуты большие успехи: были получены важнейшие стратегические данные, раскрыты машинные коды других государств, в т.ч. и Германии.

В переломные моменты войны диверсионно-разведывательные подразделения продолжали сеять хаос в рядах противника, препятствуя их продвижению вглубь страны. Во многом благодаря действиям разведки был сорван германский план молниеносной войны против Советского Союза.

\footnotetext{
1 Операция «Арийцы»: СМЕРШ против Абвера. - Военное обозрение. 10.02.2012. Доступ: https://topwar.ru/11052-operaciya-ariycy-smersh-protiv-abvera.html (проверено 26.02.2020).
} 
Например, во время битвы за Москву, куда были переправлены несколько десятков радиодивизий, была выстроена отлаженная система предупреждения о направлении авиационных ударов противника, слежка за перебросами войск. Были предотвращены опасные налеты на столицу, оккупация Тулы, т.е. наступление на Москву со стороны Южного фронта. После контрнаступления разведывательные отряды были заброшены в тыл врага и мешали ему проводить транспортные, коммуникационные сети.

Трудности разведки на начальном этапе войны были обусловлены общей структурной неготовностью разведывательного управления к войне и его недостаточной связью с высшим руководством государства. Но к 1943 г. ошибки в работе были устранены, и разведка начала работать более эффективно.

Перед началом Сталинградской битвы наши разведчики успешно раскрыли дезинформацию о готовящемся новом наступлении на Москву летом 1942 г. (операция вермахта «Кремль» провалилась). К тому моменту, как немцы подошли к Сталинграду, в их тылу работали десятки диверсионных групп радистов, передававших сведения об изменениях в позициях противника. Подразделения донской и северокавказской разведки работали сообща и помогли точнее увидеть реальную позицию вражеской армии. В результате предоставления неверной информации абверу (германская разведка) армия Паулюса под Сталинградом оказалась в окружении; была одержана нелегкая победа.

«Остались позади полные драматизма и ожесточения бои в Сталинграде. Теперь, когда левое крыло громадного советско-германского фронта под ударами наших войск покатилось на запад, дивизия, которая находилась на формировании, готовилась к наступательным операциям. А это требовало некоторой переориентировки и подготовки разведчиков к предстоящим боям» [Фокин 2006: 31].

Курская битва планировалась как масштабная наступательная операция, но, благодаря добытым агентами в Швейцарии и Англии данным, руководство Советского Союза почти доподлинно знало планы Германии в этом направлении: операция «Цитадель» была обречена на провал еще за 2 месяца до своего начала. Неоценимый вклад в победу под Курском внесла распространяемая в рядах врага дезинформация, которая ввела в заблуждение руководство вермахта.

На завершающем этапе Великой Отечественной войны отличилась воздушная разведка: снимки, полученные благодаря вылетам нашей авиации на вражескую территорию, раскрывали места размещения резервов, расположение противника и границы его оборонительных рубежей. Диверсионная работа отрядов, работавших в тылу, также была важна для достижения победы, т.к. подрывала остатки надежды нашего врага на победу.

Внешняя разведка выясняла подлинные планы союзников СССР по антигитлеровской коалиции в отношении сроков открытия «второго фронта», их позиции на совещаниях Большой тройки.

Разведка получила и своевременно направила в Москву документальные данные о намерениях союзников в отношении послевоенного устройства Европы. Благодаря полученным разведчиками сведениям о сепаратных переговорах в Швейцарии руководителя резидентуры США А. Даллеса с нацистами, удалось сорвать планы гитлеровцев по внесению раскола в ряды антигитлеровской коалиции.

В результате добытых разведкой в годы войны сведений о разработке в США и Англии атомного оружия нашей стране удалось в трудные послевоенные годы создать собственную бомбу и преодолеть монополию США в этой области [Рашевский 2010: 7]. 
И в заключение следует отметить, что советская военная разведка, патриоты нашей страны, находящиеся в тылу солдаты, агенты, работавшие под прикрытием, партизаны и организаторы повстанческих и национально-освободительных движений в оккупированных регионах, дешифровщики и радисты рисковали собственными жизнями, чтобы добыть те, возможно незначительные, крупицы информации, которые позже смогли спасти сотни, а то и тысячи жизней, отдавая долг службы и верности своей Родине. Они подарили жизнь новым поколениям, которые не должны больше знать войны и горя. Именно поэтому важно сохранять память о подвигах нашего народа, чтобы война не повторилась вновь.

\section{Список литературы}

Василевский А.М., Конев И.С., Рокоссовский К.К. 2016. Жуков и Сталин. М.: Алгоритм. 240 с.

Даллес А. 1992. Искусство разведки. М.: Международные отношения. 287 с.

Долгополов Н.М. 2018. Легендарные разведчики. На передовой вдали от фронта - внешняя разведка в годы Великой Отечественной войны. М.: Молодая гвардия. $367 \mathrm{c}$.

Жмакин М.С. 2017. Смери vs Абвер. Секретные операции и легендарные разведчики. М.: Рипол Классик. 384 с.

Максимов А.Б. 2016. Тайный фронт Великой Отечественной. М.: Вече. 480 с.

Рашевский А.А. 2010. Роль внешней разведки в годы Великой Отечественной войны. - Вестник Волэсского университета им. В.Н. Татищева. № 5. С. 4-11.

Фокин Е.И. 2006. Хроника рядового разведчика. М.: Центрполиграф. 285 с.

\section{ACTIVITIES OF SOVIET FOREIGN MILITARY INTELLIGENCE DURING THE GREAT PATRIOTIC WAR (1941-1945)}

\footnotetext{
Abstract. The article is devoted to the activities of Soviet foreign military intelligence during the Great Patriotic war. The author examines the exploits of the scouts in the struggle against Nazi Germany and the countries under its control. The paper analyzes the structure of the intelligence agencies working behind enemy lines, determines the tasks assigned to the intelligence and the results of their implementation, and estimates the contribution to the victory in the war and the importance of intelligence operations in the overall picture of events.

This topic is relevant today, when secret archives are disclosed and their contents become public, people learn more and more names of the heroes of the Great Patriotic War. It is very important to keep the memory of their exploits in the memory of Russian youth, thus cultivating respect for our history.

Keywords: foreign intelligence, intelligence officer, rear, counterintelligence, agent, feat
} 